УДК 330.5

\title{
ТЕОРЕТИЧНІ АСПЕКТИ ВИЗНАЧЕННЯ ЕКОЛОГІЧНОЇ БЕЗПЕКИ ПІДПРИЄМСТВА
}

\section{THEORETICAL ASPECTS OF DEFINITION ENVIRONMENTAL SAFETY OF THE ENTERPRISE}

\author{
Артюх-Пасюта Олена Василівна \\ кандидат економічних наук, доцент, \\ Полтавський інститут економіки і права Університету «Україна» \\ ORCID: https://orcid.org/0000-0003-4990-8565 \\ Мілька Алла Іванівна \\ кандидат економічних наук, доцент, \\ Вищий навчальний заклад Укоопспілки \\ «Полтавський університет економіки і торгівлі» \\ ORCID: https://orcid.org/0000-0003-1394-6746
}

Artyukh-Pasyuta Olena

Poltava Institute of Economics and Law, University «Ukraine»

\author{
Milka Alla \\ Higher Educational Establishment of Ukoopspilka \\ "Poltava University of Economics and Trade"
}

\begin{abstract}
Стаття присвячена аналізу сутності поняття «екологічна безпека підприємства». Досліджено та виокремлено змістовні характеристики чотирьох законів екології за Баррі Коммонером. З'ясовано, що від часів античності до новітньої історії породжені складністю феномену безпеки численні дослідження її суб'єкт-об'єктних характеристик стали основою для розвитку загальної теорії безпеки, у тому числі і екологічної безпеки. Розглянуто точки зору різних науковців щодо трактування «екологічна безпека». Незважаючи на велику кількість праць, присвячених дослідженню даної десрініції, серед вчених дотепер відсутня єдина точка зору щодо трактування категорії «екологічна безпека». Виділено правовий, економічний, системний, захисний, процесний, збалансований, комплексний, діяльнісний підходи до визначення поняття «екологічна безпека». На основі проведеного дослідження запропоновано власне визначення поняття «екологічна безпека підприємства».

ключові слова: безпека, довкілля, екологія, екологічна безпека, екологічна безпека підприємства.
\end{abstract}

Статья посвящена анализу сущности понятия «экологическая безопасность предприятия». Исследованы и выделены содержательные характеристики четырех законов экологии Барри Коммонера. Выяснено, что со времен античности до новейшей истории порожденные сложностью феномена безопасности многочисленные исследования ее субъект-объектных характеристик стали основой для развития общей теории безопасности, в том числе и экологической безопасности. Рассмотрены точки зрения различных ученых об трактовках «экологическая безопасность». Несмотря на большое количество работ, посвященных исследованию данной дефиниции, среди ученых до сих пор отсутствует единая точка зрения относительно трактовки категории «экологическая безопасность». Выделено правовой, экономический, системный, защитный, процессный, сбалансированный, комплексный, деятельностный подходы к определению понятия «экологическая безопасность». На основе проведенного исследования предложено собственное определение понятия «экологическая безопасность предприятия».

Ключевые слова: безопасность, окружающая среда, экология, экологическая безопасность, экологическая безопасность предприятия.

Due to the real environmental danger to the environment, the state, businesses, human life and health due to the many threats of natural, man-made and socio-political factors, more and more attention is paid to environmental safety. Therefore, the problem of determining the essence and content of the category of environmental safety of the enterprise in the modern development of the economy and the implementation of the prospects of European integration of Ukraine is relevant. The purpose of the article is to group and systematize the existing scientific approaches to defining 
the concept of environmental safety to justify the content of environmental safety of the enterprise. The substantive characteristics of the four laws of ecology according to Barry Commoner are studied and singled out, in particular: everything connected with everything - the complexity and interconnectedness of ecosystems; everything must move - the consequences of one ecological process give rise to another process; nature knows best - any significant anthropogenic change in the natural system can be detrimental to this system; nothing arises from nothing - the exploitation of nature always leads to environmental losses. It has been found that from the time of antiquity to modern history, numerous complex studies of its subject-object characteristics, generated by the complexity of the security phenomenon, became the basis for the development of general security theory, including environmental security. Legal, economic, systemic, protective, procedural, balanced, complex, activity approaches to the definition of "environmental safety" are highlighted. Having analyzed the existing approaches to defining the essence of the concept of "environmental safety", it is proposed to understand the environmental safety of the enterprise first: protection of vital interests of the enterprise from real and potential environmental threats to the internal and external environment; secondly: it is a sustainable balanced development of the enterprise in terms of effective and efficient management, aimed at minimizing the negative economic, environmental and social consequences of its operation as an element of the ecological and economic system, characterized by steady reduction of damage to the environment, the state and other businesses, short-term and long-term. The author's definition of environmental safety of the enterprise maintains balance and equilibrium in the triad «ecology-economy-society», creates potential opportunities to confront external and internal threats and challenges, provides sustainable balanced development of the enterprise.

Keywords: safety, environment, ecology, ecological safety, ecological safety of the enterprise.

Постановка проблеми. У зв'язку з наявністю реальної екологічної небезпеки для довкілля, держави, суб'єктів господарювання, життя та здоров'ю людей внаслідок дії багатьох загроз природних, техногенних і соціально-політичних сракторів все більше уваги приділяється екологічній безпеці. Тому проблема визначення сутності й змісту категорії екологічна безпека підприємства на сучасному розвитку економіки та реалізації перспектив європейської інтеграції України $€$ актуальною.

Аналіз останніх досліджень і публікацій. Проблемам екологічної безпеки присвячено праці таких науковців, як Андрейцев В. І., Бригадир І. В., Варламова І. С., Гетьман А. П., Ілляшенко О. В., Костецький М. Р., Малишко М. І., Махмуд А. А., Судакова О. І., Тендюк А. О., Федотова І. В., Хвесика М. А. та інші.

Виділення невирішених раніше частин загальної проблеми. Надаючи позитивну оцінку усім проаналізованим науковим здобуткам зазначених вчених, слід зазначити, що досі залишається дискусійним питання змістовного наповнення екологічної безпеки підприємства.

Формулювання цілей статті (постановка завдання). Метою статті $€$ групування і систематизація існуючих наукових підходів до визначення поняття екологічної безпеки для обґрунтування змістовного наповнення екологічної безпеки підприємства.

Виклад основного матеріалу дослідження. Неусталеність понятійно-категоріального апарату науки про екологічну безпеку пов'язана передусім з тим, що кате- горія «екологічна безпека підприємства» порівняно недавно з'явилася в понятійному апараті екологічної науки. I як усяке нове поняття, вона ще не має загальновизнаного тлумачення, адже не існує єдиної думки вчених у ссрері екологічної безпеки щодо змісту цього терміна.

Характеризуючи визначення екологічної безпеки, необхідно враховувати, що його основу становить синтез двох понять «екологія» та «безпека». Поняття «екологія» ототожнюється 3 поняттям «навколишнє природне середовище», «безпека» із захищеністю.

Екологічний зміст поняття «екологічна безпека» розкривається через закони екології, викладені відомим американським екологом Баррі Коммонером у вигляді афроризмів у 1966 році: все пов'язане з усім - складність і взаємопов'язаність екосистем; все мусить рухатися - наслідки одного екологічного процесу породжують інший процес; природа знає краще - будь-яка значна антропогенна зміна в природній системі може стати згубною для цієї системи; нічого не виникає 3 нічого - експлуатація природи завжди призводить до екологічних втрат [11].

Складність френомену безпеки породжує численні дослідження 'іï суб'єктоб'єктних характеристик на початку епохи Відродження. Англійський фрілософ Т. Гоббс («Левіафран») уперше обґрунтував теорію безпеки з позиції системного аналізу взаємодії людини, суспільства і держави в контексті створення умов для їх виживання. Саме державу він вважав суб'єктом безпеки, а безпеку громадян - метою держави. Водночас 
під забезпеченням безпеки розуміється не виключно безпека існування, а й забезпечення кожній людині всіх благ життя, здобутих законною працею, безпечною та нешкідливою для держави. Цікавим $€$ трактування Т. Гоббсом безпеки людської особистості, під якою він розумів збереження життя та забезпечення засобів такого збереження життя, за яким останнє не стало б важким [6]. У сучасній безпековій теорії цей концепт $є$ предметом соціогуманітарної безпеки.

У наукових дослідженнях Канта «Щодо вічного миру» та Гегеля «Філософрія історії», «Філософрія права» приділялася увага ролі права та держави у забезпеченні безпеки людини та суспільства. Проблеми зовнішньої та внутрішньої безпеки розвивалися в працях Монтеск'є, Бентама, Берка, Липинського, Донцова та інших [20, с. 60-61, 156-161].

Узагальнюючи фрілософрські підходи до терміна «безпека», визначаємо, що досліджуване поняття розглядається як стан захищеності, відсутності загроз з боку різних чинників.

Подібне визначення міститься і в довідковій літературі, де безпека розглядається як відсутність загрози для об'єкта 3 боку внутрішніх та зовнішніх чинників [4, с. 43]. Залежно від походження загроз, природи їх виникнення виділяється безпека екологічна, економічна, політична, військова та інші.

Досліджуючи правове поняття екологічної безпеки, слід звернути увагу на наукові дослідження Андрейцева В. І. Науковець констатує, що екологічна безпека як юридична категорія - це складова національної і транснаціональної безпеки, тобто такий стан розвитку суспільних правовідносин і відповідних їм правових зв'язків, за яких системою правових норм, інших державно-правових і соціальних засобів гарантується захищеність права громадян на безпечне для життя і здоров'я довкілля, забезпечується регулювання здійснення екологічно небезпечної діяльності і запобігання погіршенню стану довкілля та інших наслідків, небезпечних для життя і здоров'я особи, суспільства і держави, яка потребує чіткої конституціоналізації в чинному законодавстві [1, с. 38].

У Надежденко А. О. [15, с. 87]: екологічна безпека - система, що представляє собою сукупністю взаємопов'язаних та взаємозалежних елементів (суб'єктів, діяльності, засобів) цілеспрямованого впливу на довкілля шляхом реалізації механізмів екологічного управління 3 метою стратегічного екологічного розвитку суспільства в умовах збереження навколишнього природного середовища, гармонізації взаємовідносин суспільства та природи, забезпечення екологічної безпеки та захисту здоров'я людини.

Бригадир І. В. [2, с. 113]; Судакова О. І., Судакова Д. А. [17, с. 62]; Федотова І. В. $[19$, с. 32] зазначають, що екологічна безпека - це стан захищеності всіх важливих інтересів об'єкта від загроз з боку забруднених природних об'єктів. При цьому об'єктами захисту виступають: держава, суспільство, особистість, території промислового або природного об'єкта).

Науковці Козін В. В., Петровський В. А. тлумачать екологічну безпеку як «сукупність процесів, що не призводить до життєво важливим загрозам природному середовищу і людині» [10].

На сучасному етапі поглиблюється розуміння того, що необхідно розглядати поняття «екологічної безпеки» 3 точки зору тріади «екологія-економіка-соціум». До цього підходу можна навести дослідження Варламової І. С. [3, С. 163]; Ілляшенко О. В., Будрик О. І. [8, с. 73]; Махмуд А. А. [14, с. 7], Хвесик М. А. [7], які розглядають досліджуване поняття як здатність системи «довкілля - соціум економіка» зберігати рівновагу і збалансованість на основі динамічного відновлення і самовдосконалення, протистояти зовнішнім і внутрішнім загрозам, викликам та забезпечувати прийнятні рівні ризику життєдіяльності населення і стійкості соціально-економічного розвитку, а також відтворення природного і соціально-економічного потенціалу.

У літературних джерелах [3, с. 163; 18 , с. 291-292] розповсюдженим $€$ комплексний підхід, який розглядає трактування «екологічної безпеки» 3 точки зору трьох аспектів: антропоцентричного, ресурсноантропоцентричного і антропо-біоцентричного. 3 позицій антропоцентричного аспекту екологічну безпеку розглядають як стан захищеності виключно людини і суспільства. У ресурсно-екологічному аспекті об'єктами забезпечення екологічної безпеки є людина і природні ресурси; антропо-біоцентричному об'єктами гарантування екологічної безпеки виступають людина і біоресурси.

Заслуговує на увагу підхід до визначення екологічної безпеки, за яким її розуміють як певний вид діяльності. Так, М. І. Малишко розглядає екологічну безпеку як систему заходів, спрямованих на захист життєво необхідних інтересів людини від несприят- 


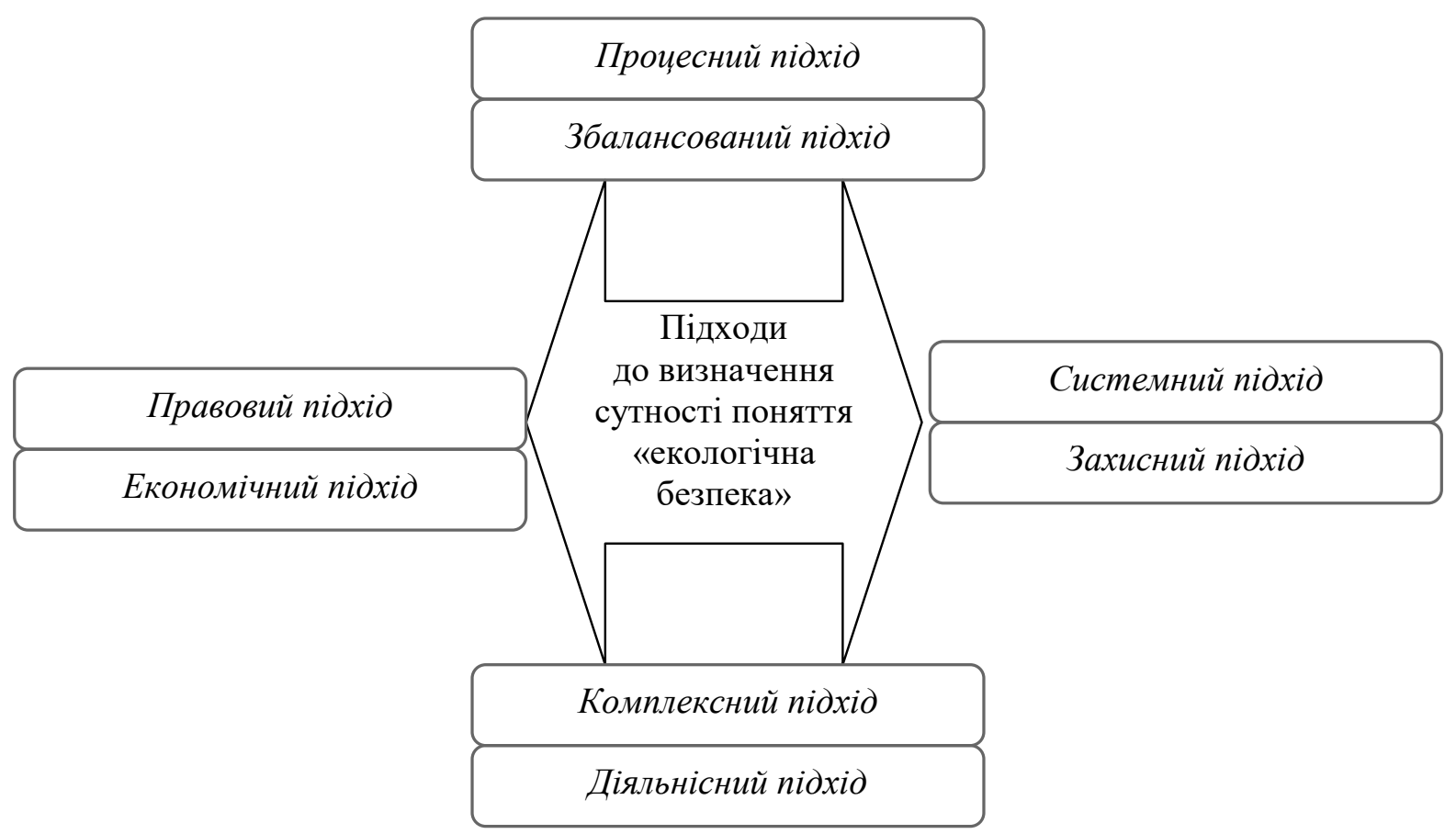

Рис. 1. Підходи до визначення сутності поняття «економічна безпека»

Джерело: розроблено авторами

ливого впливу навколишнього природного середовища, слушно вказуючи при цьому, що екологічна безпека $є$ центральним питанням екології людини, оскільки безпосереднім об'єктом охорони є людина, її економічні інтереси, екофронд [13, с. 331-335].

Своє бачення стосовно визначення місця і ролі екологічної безпеки в системі управління підприємством пропонують Ілляшенко О. В., Будрик О. І. [8]; Костецький М. Р. [12, с. 8]; Пашнюк Л. О. [16]. Науковці вважають, що екологічна безпека $\epsilon$ нічим іншим, як «гарантії економічного розвитку підприємства, на основі безпечного використання зовнішнього і внутрішнього соціально-економічного, природноресурсного та мінеральносировинного потенціалу»; «функціональна складова економічної безпеки підприємства, що забезпечує дотримання чинних екологічних норм, мінімізує втрати від забруднення довкілля та руйнівного впливу результатів виробничогосподарської діяльності підприємства на стан довкілля. Також, відмічаємо, що підприємство з еколого-економічної точки зору необхідно розглядати як головний елемент еколого-економічної системи та суб'єкт еколого-економічних відносин. Управління підприємством будується на основі збалансованого розв'язку екологічних і економічних проблем, знаходження оптимального співвідношення між забезпеченням екологічної безпеки та доцільності діяльності промислових підприємств.

Варто відзначити, що за даним підходом екологічна безпека розглядається як економічна цінність, що має свою грошову оцінку.

На підставі аналізу думок науковців можемо узагальнити існуючі підходи до визначення сутності екологічної безпеки 3 урахуванням наявних ключових положень (рис. 1).

Висновки. Авторами виділено підходи до екологічної безпеки, а саме: правовий, економічний, системний, захисний, процесний, збалансований, комплексний, діяльнісний.

Проаналізувавши наявні підходи до визначення сутності поняття «екологічна безпека», пропонуємо під екологічною безпекою підприємства розуміти по-перше: захищеність життєво важливих інтересів підприємства від реальних і потенційних екологічних загроз внутрішнього та зовнішнього середовища; по-друге: це стабільний збалансований розвиток підприємства в умовах ефективного та результативного управління, спрямований на мінімізацію негативних економічних, екологічних та соціальних наслідків його фрункціонування як елемента еколого-економічної системи, що характеризується стійким зниженням збитку довкіллю, державі та іншим суб'єктам господарювання в короткостроковій та довгостроковій перспективі. 


\section{СПИСОК ВИКОРИСТАНИХ ДЖЕРЕЛ:}

1.Андрейцев В. І. Право екологічної безпеки : навч. та наук.-практ. посіб. Київ : Знання-Прес, 2002. 332 с.

2.Бригадир І. В. Щодо визначення екологічної безпеки як правової категорії. Форум права. 2010. № 4. C. 109-114.

3.Варламова І. С. Теоретичні підходи до визначення поняття «Екологічна безпека». Науковий вісник Херсонського державного університету. 2017. Вип. 23. Ч. 2. С. 161-164.

4.Великий тлумачний словник сучасної української мови (з дод. і допов.) / уклад. і голов. ред. В. Т. Бусел. Київ; Ірпінь : ВТФ «Перун», 2005. 1728 с.

5.Гетьман А. П., Шульга М. В. Екологічне право України : підручник. Харків : Право, 2005. 328 с.

6.Гоббс Т. Левіафран, або Суть, будова і повноваження держави церковної та цивільної / Т. Гоббс ; пер. з англ. Р. Димерець та ін. ; наук. ред. Т. Польська. Київ : Дух і Літера, 2000. 600 с.

7.Екологічна і природно-техногенна безпека України в регіональному вимірі : монографія / за ред. М. А. Хвесика. Київ : ДУ «Інститут економіки природокористування та сталого розвитку НАН України», 2014 р. 340 с.

8. Ілляшенко О. В., Будрик О. І. Еколого-економічна безпека підприємства: теоретичні аспекти. Економічна стратегія і перспективи розвитку сфери торгівлі та послуг. 2017. Вип. 1(25). С. 72-82.

9. Історія вчень про державу і право : підручник / за ред. Г. Г. Демиденка, О. В. Петришина. Харків : Право, 2009. $256 \mathrm{C}$.

10. Козин В. В., Петровский В. А. Геоэкология и природопользование. Понятийно-терминологический словарь. Смоленск : Изд-во «Ойкумена», 2005. 576 с.

11. Коммонер Б. Замыкающийся круг. Л. : Гидрометеоиздат, 1974. 280 с.

12. Костецький М. Р. Система управління еколого-економічною безпекою підприємства : автореср. дис. ... канд. екон. наук : 08.00.04. Київ : ПВН3 «Європейський університет», 2010. 21 с.

13. Малишко М. І. Екологічне право України : навч. посіб. Київ : Видавничий Дім «Юрид. книга», 2001. 389 с.

14. Махмуд А. А. Екологічна безпека як предмет політики міжнародного співробітництва : автореф. дис. ... канд. політ. наук : 23.00.02. Київ, 2000. 24 с.

15. Надежденко А. О. Теоретичні підходи до визначення поняття «екологічна політика». Держава та регіони. 2011. № 1. С. 84-87.

16. Пашнюк Л. О. Економічна безпека підприємства: сутність, складові та фрактори забезпечення. URL: http://www.investplan.com.ua/pdf/22_2012/12.pdf (дата звернення: 20.04.2021).

17. Судакова О. І., Судакова Д. А. Забезпечення екологічної безпеки виробничих підприємств. URL: http://www.confcontact.com/20110629/2_sudakova.php (дата звернення: 22.04.2021).

18. Тендюк А. О., Абрамова І. О. Забезпечення екологічної безпеки як мета регіонального екологічного менеджменту: теоретико-методичні аспекти. URL: file:///C:/Users/Helen/Downloads/ecnre_2017_14_32.pdf (дата звернення: 24.04.2021).

19. Федотова І. В. Оцінювання рівня екологічної безпеки автотранспортного підприємства. Економіка транспортного комплексу. 2017. Вип. 29. С. 30-40.

20. Юркевич Памсріл. Історія фрілософрії права. Філософрія права : Філософрський щоденник. Київ : Редакція журналу «Український Світ», 2000. 769 с.

\section{REFERENCES:}

1.Andreytsev V.I. (2002) The law of environmental safety: textbook. and scientific-practical. way. Kyiv: Knowledge Press, $332 \mathrm{p}$.

2.Brigadier I.V. (2010) On the definition of environmental safety as a legal category. Law Forum, no. 4, pp. 109-114.

3.Varlamova I.S. (2017) Theoretical approaches to the definition of "Environmental Safety". Scientific Bulletin of Kherson State University, no. 23, ch. 2, pp. 161-164.

4.Large explanatory dictionary of the modern Ukrainian language (with additions and additions) (2005) / style. and heads. ed. W. T. Busel. Kyiv; Irpen: VTF "Perun", 1728 p.

5. Hetman A.P., Shulga M.V. (2005) Ecological law of Ukraine: textbook. Kharkiv: Pravo, 328 p.

6. Hobbes T. (2000) Leviathan, or the essence, structure and powers of the church and civil state / T. Hobbes; lane. from English R. Dimerets and others.; Science. ed. T. Polish. Kyiv: Spirit and Letter, 600 p.

7.Ecological and natural-technogenic safety of Ukraine in the regional dimension: monograph (2014) / ed. M.A. Hvesika. Kyiv: State Institution "Institute of Economics of Nature Management and Sustainable Development of the National Academy of Sciences of Ukraine", $340 \mathrm{p}$.

8. llyashenko O.V., Budryk O.I. (2017) Ecological and economic safety of the enterprise: theoretical aspects. Economic strategy and prospects for trade and services, no. 1(25), pp. 72-82. 
9. History of the doctrine of state and law: a textbook (2009) / ed. G.G. Demidenko, O.V. Petrishina. Kharkiv: Pravo, $256 \mathrm{p}$.

10. Kozin V.V., Petrovsky V.A. (2005) Geoecology and nature management. Conceptual and terminological dictionary. Smolensk: Oikumena Publishing House, 576 p.

11. Commoner B. (1974) Closing circle. L.: Gidrometeoizdat, 280 p.

12. Kostetsky M.R. (2010) Management system of ecological and economic safety of the enterprise: author's ref. dis. ... cand. econ. science: 08.00.04. Kyiv: European University, 21 p.

13. Malyshko M.I. (2001) Ecological law of Ukraine: textbook. way. Kyiv: Publishing House "Law. book", 389 p.

14. Mahmud A.A. (2000) Ecological safety as a subject of policy of international cooperation: author's ref. dis. ... cand. flight. science: 23.00 .02 . Kyiv, 24 p.

15. Nadezhdenko A.A. (2011) Theoretical approaches to the definition of "environmental policy". State and regions, no. 1 , pp. 84-87.

16. Pashnyuk L.O. Economic security of the enterprise: essence, components and factors of provision. URL: http://www.investplan.com.ua/pdf/22_2012/12.pdf (accessed 20 April 2021).

17. Sudakova O.I., Sudakova D.A. Ensuring environmental safety of industrial enterprises. URL: http://www.confcontact.com/20110629/2_sudakova.php (accessed 22 April 2021).

18. Tendyuk A.A., Abramova I.O. Ensuring environmental safety as a goal of regional environmental management: theoretical and methodological aspects. URL: file://C:/Users/Helen/Downloads/ecnre_2017_14_32.pdf (accessed 24 April 2021).

19. Fedotova I.V. (2017) Estimation of the level of ecological safety of the motor transport enterprise. Economics of the transport complex, vol. 29, pp. 30-40.

20. Yurkevich Pamfil (2000) History of philosophy of law. Philosophy of Law : Philosophical Diary. Kyiv: Magazine editorial office «Ukrainian World», $769 \mathrm{p}$. 